The FASEB Journal express article 10.1096/fj.00-0836fje. Published online June 8, 2001.

\title{
Glucocorticoid receptors are required for up-regulation of neuronal 5-lipoxygenase (5LOX) expression by dexamethasone
}

Tolga Uz*, Yogesh Dwivedi*, Albi Qeli*, Marc Peters-Golden ${ }^{\dagger}$, Ghanshyam Pandey*, and Hari Manev*

*The Psychiatric Institute, Department of Psychiatry, College of Medicine, University of Illinois at Chicago, Chicago, Illinois; ${ }^{\dagger}$ Pulmonary and Critical Care Medicine Division, Department of Internal Medicine, University of Michigan Medical Center, Ann Arbor, Michigan

Corresponding author: Hari Manev, The Psychiatric Institute, The University of Illinois at Chicago, 1601 West Taylor St., MC 912, Chicago, IL 60612. E-mail: HManev@psych.uic.edu

\section{ABSTRACT}

5-lipoxygenase (5LOX) is the key enzyme in the synthesis of leukotrienes from arachidonic acid. Hyperglucocorticoidemia, dexamethasone, and aging up-regulate 5LOX in the brain, including the cerebellum in vivo. We studied the mechanisms of dexamethasone-triggered 5LOX upregulation in primary cultures of rat cerebellar granule neurons (CGN). We measured 5LOX mRNA and protein contents, and the formation of cysteinyl leukotrienes $\left(\mathrm{LTC}_{4}, \mathrm{LTD}_{4}\right.$, and $\left.\mathrm{LTE}_{4}\right)$. The dexamethasone $(0.1 \mu \mathrm{M}$ or $1 \mu \mathrm{M})$-increased 5LOX mRNA and protein contents were already observed at $3 \mathrm{~h}$ of treatment, and they persisted for at least $24 \mathrm{~h}$. Dexamethasone also increased the content of cysteinyl leukotrienes, assayed in the presence of $2 \mu \mathrm{M}$ calcium ionophore A23187 and $10 \mu \mathrm{M}$ arachidonic acid. The stimulatory effect of dexamethasone on 5LOX expression was inhibited by the glucocorticoid receptor (GR) antagonist RU486 and by reducing the CGN content of GR receptor protein with a GR-specific antisense oligonucleotide. The 5LOX mRNA half-life was longer in dexamethasone than in vehicle-treated CGNs. Our results indicate that dexamethasone increases 5LOX expression in CGNs in a GR-dependent manner and that it also increases the stability of 5LOX mRNA. Further studies are warranted to elucidate the physiologic/pathologic significance of glucocorticoid-regulated expression of $5 \mathrm{LOX}$ in the central nervous system.

Key words: cerebellar granule neurons $\bullet$ leukotrienes $\bullet$ arachidonic acid $\bullet$ cerebellar granule neurons

\footnotetext{
5 -Lipoxygenase (5LOX) enzyme activity is crucial for the biosynthesis of inflammatory eicosanoids, leukotrienes (LTs) from arachidonic acid. 5LOX catalyzes the oxygenation of arachidonic acid, leading to formation of 5-hydroperoxyeicosatetraenoic acid (5-HPETE) and its subsequent dehydration into leukotriene $\mathrm{A}_{4}\left(\mathrm{LTA}_{4}\right)$. LTA 4 is the precursor for other LTs; that is, $\mathrm{LTB}_{4}$ and the family of cysteinyl leukotrienes (cysLTs: $\mathrm{LTC}_{4}, \mathrm{LTD}_{4}$, and $\mathrm{LTE}_{4}$ ) (1). In the brain, increased formation of cysLTs was found in response to seizures (2). Moreover, the brain also expresses a receptor specific for cysLTs, the cysteinyl leukotriene 2 receptor (3). An
} 
increased expression of 5LOX during aging was associated with increased brain vulnerability to neurodegeneration (4). Thus, it has been suggested that inflammatory mechanisms, including the 5LOX pathway, might contribute to the pathophysiology of aging-associated brain disorders, such as Alzheimer's disease $(5,6)$.

Recently, we have found that the content of 5LOX mRNA and protein in the central nervous system, including the cerebellum, increases after prolonged (10 days) treatment of rats with glucocorticoids, corticosterone, or dexamethasone (7). However, this rather unsuspected finding that anti-inflammatory hormones (i.e., glucocorticoids) whose secretion is increased in the elderly (8) also increase the expression of a proinflammatory enzyme (i.e., 5LOX) is not without precedent. Thus, it was reported recently that dexamethasone increases 5LOX mRNA and protein in human mast cells (9), and in human peripheral blood monocytes and the acute monocytic leukemia cell line, THP-1 (10). The exact mechanism of glucocorticoid-stimulated $5 \mathrm{LOX}$ expression is not clear.

In this study, we used primary cultures of rat cerebellar granule neurons (CGN) to characterize in vitro the mechanism of action of dexamethasone on 5LOX. Rat CGNs have been identified previously as one of the neuronal cell types that express 5LOX both in vivo (11) and in vitro (12). The CGN also express the glucocorticoid receptor (GR) $(13,14)$ and thus are a suitable model to study the involvement of GRs in the action of dexamethasone.

\section{MATERIALS AND METHODS}

\section{Preparation of primary cultures of rat CGN}

CGNs were prepared from eight-day-old rat pups (Sprague Dawley; Harlan, Indianapolis, IN) as described previously (12). Cells were plated onto poly-L-lysine-coated $(5 \mu \mathrm{g} / \mathrm{ml}$, Sigma, St. Louis, MO) $100-\mathrm{mm}$ or $35-\mathrm{mm}$ dishes (for LTs assay) at a density of $1 \times 10^{6}$ cells $/ \mathrm{ml}(10$ $\mathrm{ml} / 100-\mathrm{mm}$ dish; $2 \mathrm{ml} / 35-\mathrm{mm}$ dish). Cultures were grown in a chemically defined, serum-free, B-27 supplemented neurobasal medium (Gibco BRL, Rockville, MD) containing $2 \mathrm{mM} \mathrm{L-}$ glutamine, $30 \mu \mathrm{g} / \mathrm{ml}$ gentamicin sulfate, and $25 \mathrm{mM} \mathrm{KCl}$ (all from Sigma). Cultured neurons were maintained at $37^{\circ} \mathrm{C}$ in a water-saturated air environment containing $5 \% \mathrm{CO}_{2}$; they were used for experiments at 7-8 days in vitro.

\section{Drug and antisense treatments}

Dexamethasone (RBI), the GR antagonist RU486 (a gift from Christoph Kellendonk), or the calcium ionophore A23187 (Sigma) were dissolved in dimethylsulfoxide (DMSO; Sigma). Stock solutions or their vehicles were applied directly to the culture medium $(1 \mu \mathrm{l} / \mathrm{ml}$ medium). The GR antisense (AS) and the corresponding control, scramble (SCRM) oligonucleotides were prepared based on the previously published report (15); AS: GGATTCTTTGGAGTCCAT, SCRM: AATGCTCGCTTGATGTTG (Integrated DNA Technologies Inc., Coralville, IA). Oligonucleotides were dissolved in the culture medium and were added to the cells twice $(24 \mathrm{~h}$ at 12-h intervals; final concentration $10 \mu \mathrm{M}$ ); cells were processed $12 \mathrm{~h}$ after the second application of oligonucleotides. All experiments were repeated in at least three different CGN preparations. 


\section{RNA analysis}

Typically, one-half of the samples from each experimental group were used to isolate the total RNA, whereas the rest was used to isolate proteins. For RNA extraction, the medium was removed and neurons were harvested in $4 \mathrm{M}$ guanidine isothiocyanate, $50 \mathrm{mM}$ Tris/ $\mathrm{HCl}(\mathrm{pH}$ 7.4), and $25 \mathrm{mM}$ EDTA- $\mathrm{Na}_{2}(1 \mathrm{ml} / \mathrm{dish})$. Total RNA was isolated by $\mathrm{CsCl}_{2}$ ultracentrifugation, as described previously (16). The yield of total RNA was determined by measuring the absorbance of an aliquot of the precipitated stock at 260/280 $\mathrm{nm}$. After each extraction, possible DNA contamination was excluded by running one sample by quantitative reverse transcription/polymerase chain reaction (RT-PCR; see below) without adding the reverse transcriptase enzyme.

\section{RNA content}

This content was measured by quantitative RT-PCR with internal standards, as described earlier (17). Briefly, we used the following 5LOX-specific primers: forward $=5$ 'AAAGAACTGGAAACACGTCAGAAA-3'; reverse = 5'-AACTGGTGTGTACAG GGGTCAGTT-3', and the internal standard templates for 5LOX that were generated by sitedirected mutagenesis, as previously described $(17,18)$. Each standard was designed to introduce a $B g I I I$ restriction site midway between the amplification primers so that the digestion of the amplicon would generate two fragments of approximately equal molecular size. The selected restriction sites were introduced with only a minimal number of base substitutions. The sequences of internal standards (mutations indicated by bold, italicized letters) were as follows: forward = 5'-TCGTCAAGATCTGCAACACTATTT-3'; reverse = 3' $^{\prime}$ AGAAGCAGTTCTAGACGTTGTGAT-5'. Decreasing concentrations of 5LOX internal standard cRNA were added to $1 \mu \mathrm{g}$ of the total RNA isolated from CGN cultures. The RNA/cRNA mixtures were denaturated at $80^{\circ} \mathrm{C}$ for $6 \mathrm{~min}$ and then reverse-transcribed with Moloney murine leukemia virus (M-MLV) reverse transcriptase (Gibco BRL) in an RT buffer containing deoxynucleotide triphosphates (Gibco, BRL), random hexamers (Pharmacia Biotech, Piscataway, NJ), and ribonuclease inhibitor (HPRI; Amersham, Piscataway, NJ). The RT mixture was incubated at $37^{\circ} \mathrm{C}$ for $60 \mathrm{~min}$ to promote cDNA synthesis. The reaction was terminated by heating the samples at $98^{\circ} \mathrm{C}$ for $5 \mathrm{~min}(17,18)$. As a control, in all assays one RT reaction was performed in the absence of RNA. After termination of the RT reaction, cDNA aliquots containing reverse-transcribed material were amplified 30 cycles with Hot Tub DNA polymerase. Trace amounts of $\left[{ }^{32} \mathrm{P}\right] \mathrm{dCTP}$ (Amersham; $0.5 \mu \mathrm{Ci} / \mathrm{sample}$ ) were included during the PCR step for subsequent quantification. The reaction was terminated with a 5-min final elongation step, and products were separated by agarose gel electrophoresis. To quantify the amount of the product corresponding to the amplified mRNA, the ethidium bromide-stained bands (5LOX and the internal standard) were excised and the radioactivity was determined by Cerenkov counting (19). The results are expressed as attomol 5LOX mRNA per $\mu$ g total RNA $(17,18)$.

\section{RNA stability}


This stability was examined by measuring the half-life of the mRNA following the inhibition of the gene transcription with actinomycin D (Sigma), as described elsewhere (20). Briefly, cultured neurons were treated with dexamethasone or its vehicle for $24 \mathrm{~h}$ before the addition of actinomycin D (10 $\mu \mathrm{g} / \mathrm{ml})$. Total RNA was isolated from vehicle- and dexamethasone-treated cells at different times after actinomycin D $(2-8 \mathrm{~h})$ and 5LOX mRNA levels were measured by quantitative RT-PCR, as described above.

\section{Protein analysis}

The CGN content of 5LOX, GR, and $\beta$-actin proteins was determined by Western blot analysis Briefly, the total protein content for each sample was determined and two different concentrations $(20 \mu \mathrm{g}$ and $40 \mu \mathrm{g})$ of each sample were run on a $7.5 \%$ SDS-PAGE gel electrophoresis, as described elsewhere (12). For 5LOX and GR protein assays, we used the respective polyclonal antibodies: 5LOX by Cayman Chemicals (Ann Arbor, MI), and GR M-20 by Santa Cruz Biotechnology (Santa Cruz, CA). To normalize the signal for these two proteins, the presence of a noninducible $\beta$-actin protein was measured on the same blot by using a mouse monoclonal antibody against the $\beta$-actin (Sigma) (12). The blots were developed by the enhanced chemiluminescence system (ECL, Amersham) and exposed to ECL film (Amersham). The optical densities of the bands on the film were quantified by using the Loats Image Analysis System (Westminster, MD), and the optical densities of the 5LOX (78 kD) and GR (95 kD) bands were corrected (calculated as a ratio) by the optical density of the corresponding $\beta$-actin band $(46 \mathrm{kD})$. The values are expressed as a percent of the control.

\section{Leukotriene analysis}

The capacity of CGN cultures to synthesize LTs was measured in the presence of calcium ionophore A23187 $(2 \mu \mathrm{M})$ and arachidonic acid (10 $\mu \mathrm{M}$; Sigma) by enzyme-linked immunoassay (EIA) determination of cell-free supernatants for the predominant 5LOX products $\mathrm{LTB}_{4}$ and cysLTs (i.e., $\mathrm{LTC}_{4}, \mathrm{LTD}_{4}$, and $\mathrm{LTE}_{4}$ ) as reported earlier (21). The cultures were treated with $1 \mu \mathrm{M}$ dexamethasone or vehicle for $24 \mathrm{~h}$; thereafter, cells from each group were exposed for 20 min to arachidonic acid + A23187 (arachidonic acid was added first, A23187 was added 5 min after arachidonic acid), and the medium was collected for LT assay (21). In the absence of arachidonic acid, no LTs were detected (the lower assay limit was 13-15.6 pg/ml).

\section{Statistical analysis}

Statistical analysis of the results (mean $\pm \mathrm{SE}$ ) was performed by using ANOVA followed by the Mann-Whitney $U$ test or by the Kruskal-Wallis one-way analysis of variance on ranks; $P<0.05$ was accepted as significant.

\section{RESULTS}

Dexamethasone increases 5LOX mRNA and protein contents in CGN in a concentration- and time-dependent manner 
Exposure of CGNs to dexamethasone increased the culture's content of both 5LOX mRNA (Fig. $\underline{1 \mathrm{~A}}$ ) and 5LOX protein (Fig. 1B). These increases were concentration-dependent and became statistically significant with $100 \mathrm{nM}$ dexamethasone. Time-course studies revealed that dexamethasone treatment increased the content of 5LOX mRNA and protein as early as $3 \mathrm{~h}$, and that these increases persisted for at least $24 \mathrm{~h}$ of dexamethasone treatment (Fig. 1C, D).

\section{Dexamethasone increases the capacity of CGN to produce cysteinyl leukotrienes (cysLTs)}

The capacity of CGN to produce LTs was assayed by determination of cell-free supernatants for the predominant $5 \mathrm{LOX}$ products, $\mathrm{LTB}_{4}$, and cysLTs (i.e., $\mathrm{LTC}_{4}, \mathrm{LTD}_{4}$, and $\mathrm{LTE}_{4}$ ). Cultures were treated with $1 \mu \mathrm{M}$ dexamethasone for $24 \mathrm{~h}$ (controls were treated with a vehicle for the same period). In the last 15 min of treatment, cultures were supplemented with $10 \mu \mathrm{M}$ arachidonic acid (substrate for LT synthesis) and $2 \mu \mathrm{M}$ A23187 (calcium ionophore; calcium is required for full 5LOX enzymatic activity). In the absence of added arachidonic acid, we did not detect LTs in the culture medium, even if these cultures were treated with A23187. After adding arachidonic acid and A23187, we readily detected cycLTs but not $\mathrm{LTB}_{4}$ (the lower limit of detection was 13 $\mathrm{pg} / \mathrm{ml}$ ), and the content of cysLTs was greater in cultures pretreated with dexamethasone than in the corresponding controls: vehicle $=45.8 \pm .7$; dexamethasone $=64.7 \pm 5.7^{*}(\mathrm{pg} / \mathrm{ml} ; n=8$ per group; * $P<0.01$ ). We detected only $\mathrm{LTB}_{4}$ (about $20 \mathrm{pg} / \mathrm{ml}$ ) in few samples from dexamethasonepretreated cultures.

\section{Dexamethasone-up-regulated 5LOX expression requires the $\mathbf{G R}$}

We verified the expression of GRs in our preparation of CGNs with a specific anti-GR antibody (Fig. 2A). Using antisense technology, we significantly reduced the content of GRs in CGN cultures (Fig. 2B). GR AS and the corresponding SCRM oligonucleotides (see Materials and Methods for details) were injected directly into the culture medium twice in $24 \mathrm{~h}$, at $12-\mathrm{h}$ intervals; $12 \mathrm{~h}$ after the second treatment, cells were harvested for GR protein measurements. Application of antisense to GRs reduced the content of GR protein by more than $50 \%$ compared with SCRM-treated controls (Fig. 2B). Thus, we used antisense methodology to investigate whether alterations in GR content in CGN also alter the effects of dexamethasone on 5LOX expression (i.e., mRNA and protein levels). When GR AS or SCRM oligonucleotides were coadministrated with dexamethasone, GR AS but not SCRM could suppress the dexamethasoneinduced increase in 5LOX mRNA and protein content (Fig. 3).

To investigate whether the stimulatory effect of dexamethasone on 5LOX expression occurs via the GRs, we used the GR antagonist RU486. After co-administration of $1 \mu \mathrm{M}$ dexamethasone (or its vehicle) and $1 \mu \mathrm{M}$ RU486 (or its vehicle) to CGNs for $24 \mathrm{~h}, 5 \mathrm{LOX}$ mRNA and protein levels were quantified. We found that RU486 significantly reduced dexamethasone-stimulated 5LOX expression (Fig. 3). However, RU486 did not alter the basal levels of 5LOX mRNA and protein (Fig. 3).

\section{Dexamethasone increases the half-life of 5LOX mRNA in CGNs}


It has been suggested that the stimulatory action of dexamethasone on gene expression may include both increased transcription and posttranscriptional effects, such as prolongation of an mRNA's half-life (22). Thus, we examined 5LOX mRNA stability in CGN cultures treated for $24 \mathrm{~h}$ with dexamethasone or its vehicle, and we estimated the half-life of 5LOX mRNA following the inhibition of gene transcription with actinomycin D (20). The half-life $\left(t_{1 / 2}\right)$ of the 5LOX mRNA in vehicle-treated cells was $4.0 \pm 0.1 \mathrm{~h}$, whereas in dexamethasone-treated CGNs, the $t_{1 / 2}$ was $5.8 \pm 0.2 \mathrm{~h}$ (i.e., about $50 \%$ longer) (Fig. 4 ).

\section{DISCUSSION}

The results we obtained in this study by using primary cultures of rat cerebellar granule neurons confirm our previous findings in the rat cerebellum in vivo (7); that is, dexamethasone treatment increased the content of 5LOX mRNA and protein in cells of the mammalian central nervous system. The stimulatory effect of dexamethasone on 5LOX in CGN was observed with concentrations as low as $100 \mathrm{nM}$, which suggests that 5LOX up-regulation occurs at a physiologically relevant concentration of glucocorticoid hormones. The advantage of the in vitro system is that it is better suited for mechanistic studies; thus, we selected the CGN cultures to characterize further the mechanisms of dexamethasone action on 5LOX expression.

Using different in vitro models of cell cultures, others have also observed 5LOX up-regulation in response to dexamethasone treatment. For example, both 5LOX mRNA and protein were increased after dexamethasone treatment (concentrations about $1 \mu \mathrm{M}$ ) in human mast cells (9) and in human monocytes and THP-1 cells (10). In those cell cultures, dexamethasone also increased the capacity of cells to produce LTs, and the authors concluded that this synthetic glucocorticoid increased 5LOX gene expression $(9,10)$. Our primary cultures of CGN express both 5LOX and the 5LOX-activating protein FLAP (12). Nevertheless, we found that they do not produce detectable levels of LTs unless provided with exogenous arachidonic acid. When provided with arachidonic acid and in the presence of the calcium ionophore, not only do these cells produce cysLTs, but also their capacity to synthesize cysLTs was increased by dexamethasone pretreatment. Thus, we also conclude that our collective data on 5LOX mRNA, 5LOX protein, and LT synthesis are consistent with the proposed $(9,10)$ stimulatory action of dexamethasone on 5LOX gene expression. In addition, it is possible that another key enzyme in cysLTs synthesis, the LTC $_{4}$ synthase (functionally similar to glutathione-S-transferases) could also be the target for dexamethasone, and that this action might contribute to increased cysLT synthesis.

Many effects of corticosteroids in the central nervous system are believed to be mediated via two types of corticosteroid receptors: mineralocorticoid receptors and GR, to which dexamethasone binds (23). Both tritiated dexamethasone autoradiograpy (24) and immunohistochemistry (25) studies showed nuclear localization of GRs in the cerebellar granule and Purkinje cells. Quantitative analysis of GR mRNA by competitive RT-PCR revealed its highest amounts in the cerebellum compared with other brain regions (26). Also our Western blot assay confirmed that CGNs in vitro express the GR protein. The functional involvement of GR in the regulation of 5LOX expression in CGNs is indicated by our findings in experiments with GR antisense oligonucleotide and with the GR antagonist RU486; both were effective in inhibiting the up- 
regulation of 5LOX expression by dexamethasone. We performed these studies using two complementary methods; that is, antisense and pharmacological inhibition, because a singlemethod approach might generate inconclusive results. In our experiments, GR antisense reduced the GR protein levels by about 50\%, which was sufficient to prevent the $24 \mathrm{~h}$ dexamethasone exposure from up-regulating 5LOX. This finding suggests that the antisense-induced reduction was capable of bringing the level of the GR protein below the amounts needed to sustain the $24 \mathrm{~h}$ action of dexamethasone because the protracted glucocorticoid treatment also decreases the GR steady-state mRNA levels by decreasing receptor gene transcription (27). However, RU486 is a potent antagonist for both intracellular GR and progesterone receptors; it binds with high affinity to these receptors and causes transconformational differences in their ligand-binding domain (28). Because both GR antisense and RU486 prevented dexamethasone from up-regulating 5LOX expression, it can be concluded that genomic mechanisms, rather than a nongenomic action that involves the activation of membrane receptors for glucocorticoids (29), mediated the effects of dexamethasone we observed in CGNs. However, it should be stressed that no obvious glucocorticoid response element has been found in the sequence of the 5LOX gene and its promoter. Thus, it remains to be established whether such a response element is located elsewhere in the genome and in relation to the 5LOX gene. Moreover, other more complex interactions of GR with genome and/or other nuclear receptors (e.g., RZRs, nuclear receptors that also affect 5LOX expression; (30)) could possibly explain the action of dexamethasone on 5LOX expression. Others who have reported the stimulatory action of dexamethasone on 5LOX expression $(9,10)$ have also entertained these possibilities.

Our finding that dexamethasone pretreatment prolonged the half-life of 5LOX mRNA suggests that mechanisms that regulate RNA stability could also contribute to the increase in 5LOX gene expression we observed. Such mechanisms are likely to include a direct action of dexamethasone on 5LOX mRNA or on mRNA-selective proteins/enzymes (31). Glucocorticoids have already been shown capable of enhancing the stability of other mRNAs such as those of the insulin receptor (32) and the growth hormone (33). Even though the molecular mechanisms of the hormonal regulation of RNA stability are not very well understood, it has been speculated that glucocorticoids may induce a factor that associates with an RNA element in the 3'untranslated region (3'UTR) of the gene (32). The latter region is critical for regulating the cytoplasmic life of a mRNA (34).

The functional significance of our findings for the physiology and/or pathology of the central nervous system remains to be fully characterized. However, available data point to a possible role for the 5LOX pathway in brain aging (35), neurodegeneration $(5,18,36,37,38)$, seizures (2), synaptic activity $(39,40)$, neurogenesis (41), and neurodevelopment (42). The stimulatory effect of dexamethasone on 5LOX expression in CGNs might be responsible for the recently observed glucocorticoid-induced increased vulnerability of these neurons to oxidative stress (43). The importance of stress-induced increases is glucocorticoid levels for heightened risk for neurodegenerative injuries is well recognized, and its relevance for the pathobiology of neuropsychiatric disorders was recently reviewed (44). Not only are the brain (42) and our neural cultures capable of synthesizing cysLTs, the brain also expresses cysLT receptors (3). Thus, it is possible that the 5LOX pathway affects brain functioning via cysLTs. However, it is also important to elucidate whether even nonenzymatic actions of 5LOX protein (4) are relevant for central nervous system functioning. 


\section{ACKNOWLEDGMENT}

This work was supported in part by the National Institute on Aging grant RO1-AG15347 (H. M.) and by grant RO1-MH56528 from the National Institute of Mental Health (G. P.).

\section{REFERENCES}

1. Peters-Golden, M. (1998) Molecular mechanisms of leukotriene synthesis: the changing paradigm. Clin. Exp. Allergy 28, 1059-1065

2. Simmet, T., Tippler, B. (1991) On the relation between cerebral cysteinyl-leukotriene formation and epileptic seizures. Brain Res. 540, 283-286

3. Heise, C. E., O'Dowd, B. F., Figueroa, D. J., Sawyer, N., Nguyen, T., Im, D. S., Stocco, R., Bellefeuille, J. N., Abramovitz, M., Cheng, R., Williams, D. L. Jr., Zeng, Z., Liu, Q., Ma, L., Clements, M. K., Coulombe, N., Liu, Y., Austin, C. P., George, S.R., O'Neill, G.P., Metters, K. M., Lynch, K. R., Evans, J. F. (2000) Characterization of the human cysteinyl leukotriene 2 receptor. J. Biol. Chem. 275, 30531-30536

4. Manev, H., Uz, T., Sukaya, K., Qu, T. (2000) Putative role of neuronal 5-lipoxygenase in an aging brain. FASEB J. 14, 1464-1469

5. Paris, D., Town, T., Parker, T., Humphrey, J., Mullan, M. (2000) A beta vasoactivity: an inflammatory reaction. Ann. N. Y. Acad. Sci. 903, 97-109

6. Manev, H. (2000) 5-Lipoxygenase gene polymorphism and onset of Alzheimer's disease. Med. Hypotheses 54, 75-76

7. Uz, T., Dwivedi, Y., Savani, P. D., Impagnatiello, F., Pandey, G., Manev, H. (1999) Glucocorticoids stimulate inflammatory 5-lipoxygenase gene expression and protein translocation in the brain. J. Neurochem. 73, 693-699

8. Magri, F., Terenzi, F., Ricciardi, T., Fioravanti, M., Solerte, S.B., Stabile, M., Balza, G., Gandini, C., Villa, M., Ferrari, E. (2000) Association between changes in adrenal secretion and cerebral morphometric correlates in normal aging and senile dementia. Dement. Geriatr. Cogn. Disord. 11, 90-99

9. Colamorea, T., Di Paola, R., Macchia, F., Guerrese, M. C., Tursi, A., Butterfield, J. H., Caiaffa, M. F., Haeggstrom, J. Z., Macchia, L. (1999) 5-Lipoxygenase upregulation by dexamethasone in human mast cells. Biochem. Biophys. Res. Commun. 265, 617-624

10. Riddick, C. A., Ring, W. L., Baker, J. R., Hodulik, C. R., Bigby T. D. (1997) Related Articles Dexamethasone increases expression of 5-lipoxygenase and its activating protein in human monocytes and THP-1 cells. Eur. J. Biochem. 246, 112-118 
11. Lammers, C. H., Schweitzer, P., Facchinetti, P., Arrang, J. M., Madamba, S. G., Siggins, G. R., Piomelli, D. (1996) Arachidonate 5-lipoxygenase and its activating protein: prominent hippocampal expression and role in somatostatin signaling. J. Neurochem. 66, 147-152

12. Manev, H., Uz, T. (1999) Primary cultures of rat cerebellar granule cells as a model to study neuronal 5-lipoxygenase and FLAP gene expression. Ann. N. Y. Acad. Sci. 890, 183-190

13. Sanchez, M. M., Young, L. J., Plotsky, P. M., Insel, T. R. (2000) Distribution of corticosteroid receptors in the rhesus brain: relative absence of glucocorticoid receptors in the hippocampal formation. J. Neurosci. 20, 4657-4668

14. Morimoto, M., Morita, N., Ozawa, H., Yokoyama, K., Kawata, M. (1996) Distribution of glucocorticoid receptor immunoreactivity and mRNA in the rat brain: an immunohistochemical and in situ hybridization study. Neurosci. Res. 26, 235-269

15. Korte, S. M., De Kloet, E. R., Buwalda, B., Bouman, S. D., Bohus, B. (1996) Antisense to the glucocorticoid receptor in hippocampal dentate gyrus reduces immobility in forced swim test. Eur. J. Pharmacol. 301, 19-25

16. Chirgwin, J. M., Przybyla, A. E., MacDonald, R. J., Rutter, W. J. (1979) Isolation of biologically active ribonucleic acid from sources enriched in ribonuclease. Biochemistry 18, 5294-5299

17. Uz, T., Longone, P., Manev, H. (1997) Increased hippocampal 5-lipoxygenase mRNA content in melatonin-deficient, pinealectomized rats. J. Neurochem. 69, 2220-2223

18. Uz, T., Pesold, C., Longone, P., Manev, H. (1998) Aging-associated up-regulation of neuronal 5-lipoxygenase expression: putative role in neuronal vulnerability. FASEB J. 12, $439-449$

19. Santi, M. R., Ikonomovic, S., Wroblewski, J. T., Grayson, D. R. (1994) Temporal and depolarization-induced changes in the absolute amounts of mRNAs encoding metabotropic glutamate receptors in cerebellar granule neurons in vitro. J. Neurochem. 63, 1207-1217

20. Pshenichkin, S. P., Wise, B. C. (1995) Okadaic acid increases nerve growth factor secretion, mRNA stability, and gene transcription in primary cultures of cortical astrocytes. J. Biol. Chem. 270, 5994-5999

21. Peters-Golden, M., Shelly, C., Morganroth, M. L. (1989) Inhibition of rat lung glutathione synthesis attenuates hypoxic pulmonary vasoconstriction and the associated leukotriene C4 production. Am. Rev. Respir. Dis. 140, 1210-1215

22. Xu, Z. X., Rooney, S. A. (1997) Glucocorticoids increase fatty-acid synthase mRNA stability in fetal rat lung. Am. J. Physiol. 272, L860-L864 
23. de Kloet, E. R., Oitzl, M. S., Joels, M. (1999) Stress and cognition: are corticosteroids good or bad guys? Trends Neurosci. 22, 422-426

24. Birmingham, M. K., Sar, M., Stumpf, W. E. (1993) Dexamethasone target sites in the central nervous system and their potential relevance to mental illness. Cell. Mol. Neurobiol. 13, 373386

25. Ahima, R. S., Harlan, R. E. (1991) Differential corticosteroid regulation of type II glucocorticoid receptor-like immunoreactivity in the rat central nervous system: topography and implications. Endocrinology 129, 226-236

26. Marlier, L. N., Patacchioli, F. R., Porzio, O., Chiusaroli, R., Borboni, P., Lauro, R., Angelucci, L. (1997) Distribution of adrenocorticoid receptors in the rat CNS measured by competitive PCR and cytosolic binding. J. Mol. Neurosci. 9, 1-12

27. Rosewicz, S., McDonald, A. R., Maddux, B. A., Goldfine, I. D., Miesfeld, R. L., Logsdon, C. D. (1988) Mechanism of glucocorticoid receptor down-regulation by glucocorticoids. J. Biol. Chem. 263, 2581-2584

28. Cadepond, F., Ulmann, A., Baulieu, E. E. (1997) RU486 (mifepristone): mechanisms of action and clinical uses. Annu. Rev. Med. 48, 129-156

29. Moore, F. L., Evans, S. J. (1999) Steroid hormones use non-genomic mechanisms to control brain functions and behaviors: a review of evidence. Brain Behav. Evol. 54, 41-50

30. Steinhilber, D., Brungs, M., Werz, O., Wiesenberg, I., Danielsson, C., Kahlen, J. P., Nayeri, S., Schrader, M., Carlberg, C. (1995) The nuclear receptor for melatonin represses 5lipoxygenase gene expression in human B lymphocytes. J. Biol. Chem. 270, 7037-7040

31. Poon, M., Liu, B., Taubman, M. B. (1999) Identification of a novel dexamethasone-sensitive RNA-destabilizing region on rat monocyte chemoattractant protein $1 \mathrm{mRNA}$. Mol. Cell Biol. 19, 6471-6478

32. Hines, D., Hug, V., Levy, J. R. (1994) Dexamethasone mediated stabilization of insulin receptor mRNA. J. Recept. Res. 14, 297-305

33. Paek I, Axel R.(1987) Glucocorticoids enhance stability of human growth hormone mRNA. Mol. Cell Biol. 7, 1496-1507

34. Wickens, M., Anderson, P., Jackson, R. J. (1997) Life and death in the cytoplasm: messages from the 3' end. Curr. Opin. Genet. Dev. 7, 220-232

35. Qu, T., Uz, T., Manev, H. (2000) Inflammatory 5-LOX mRNA and protein are increased in brain of aging rats. Neurobiol. Aging. 21, 647-652 
36. Ohtsuki, T., Matsumoto, M., Hayashi, Y., Yamamoto, K., Kitagawa, K., Ogawa, S., Yamamoto, S., Kamada, T. (1995) Reperfusion induces 5-lipoxygenase translocation and leukotriene C4 production in ischemic brain. Am. J. Physiol. 268, H1249-H1257

37. Rao, A. M., Hatcher, J. F., Kindy, M. S., Dempsey, R. J. (1999) Arachidonic acid and leukotriene C4: role in transient cerebral ischemia of gerbils. Neurochem. Res. 24, 12251232

38. Qu, T., Manev, R., Manev, H. (2001) 5-Lipoxygenase (5-LOX) promoter polymorphism in patients with early and late onset Alzheimer's disease. J. Neuropsych. Clin. Neurosci.

39. Chabot, C., Gagne, J., Giguere, C., Bernard, J., Baudry, M., Massicotte, G. (1998) Bidirectional modulation of AMPA receptor properties by exogenous phospholipase A2 in the hippocampus. Hippocampus 8, 299-309

40. Vaughan, C. W., Ingram, S. L., Connor, M. A., Christie, M. J. (1997) How opioids inhibit GABA-mediated neurotransmission. Nature (London) 390, 611-614

41. Manev, H., Uz, T., Manev, R. (2000) Putative role of neuronal 5-lipoxygenase (5-LOX) in proliferation of immature cerebellar granule cells. J. Neurochem. 74, S64

42. Mayatepek, E. (2000) Leukotriene $\mathrm{C}_{4}$ synthesis deficiency: a member of a probably underdiagnosed new group of neurometabolic diseases. Eur. J. Pediatr. 159, 811-818

43. Ahlbom, E., Gogvadze, V., Chen, M., Celsi, G., Ceccatelli, S. (2000) Prenatal exposure to high levels of glucocorticoids increases the susceptibility of cerebellar granule cells to oxidative stress-induced cell death. Proc. Natl. Acad. Sci. USA 97, 14726-14730

44. Sapolsky, R. M. (2000) Glucocorticoids and hippocampal atrophy in neuropsychiatric disorders. Arch. Gen. Psychiatry 57, 925-935 
Fig. 1
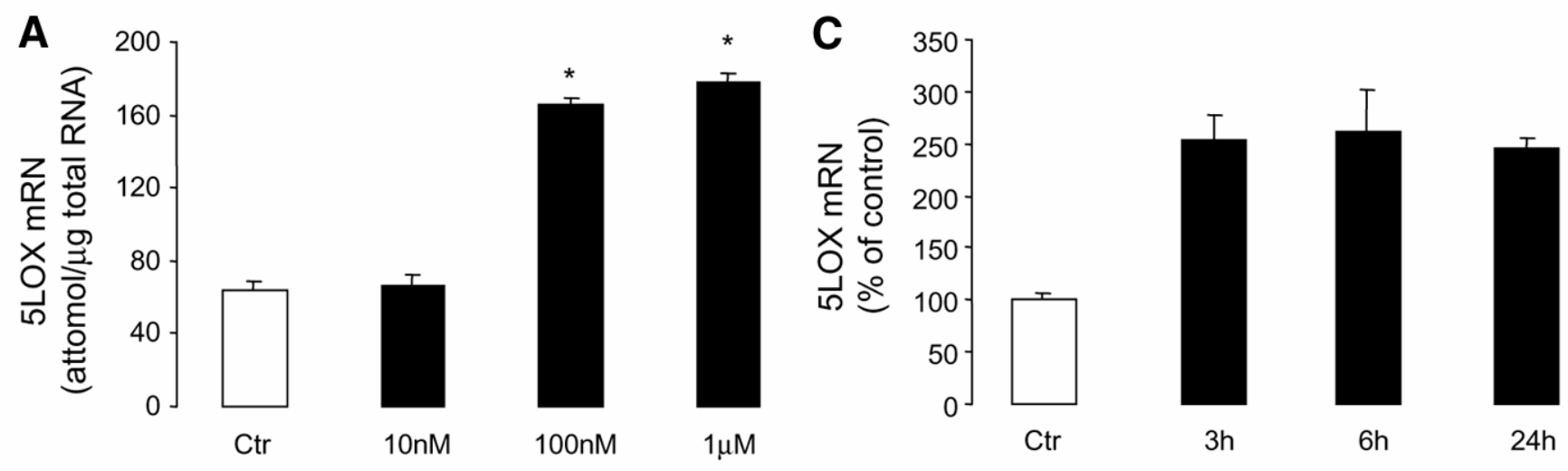

B
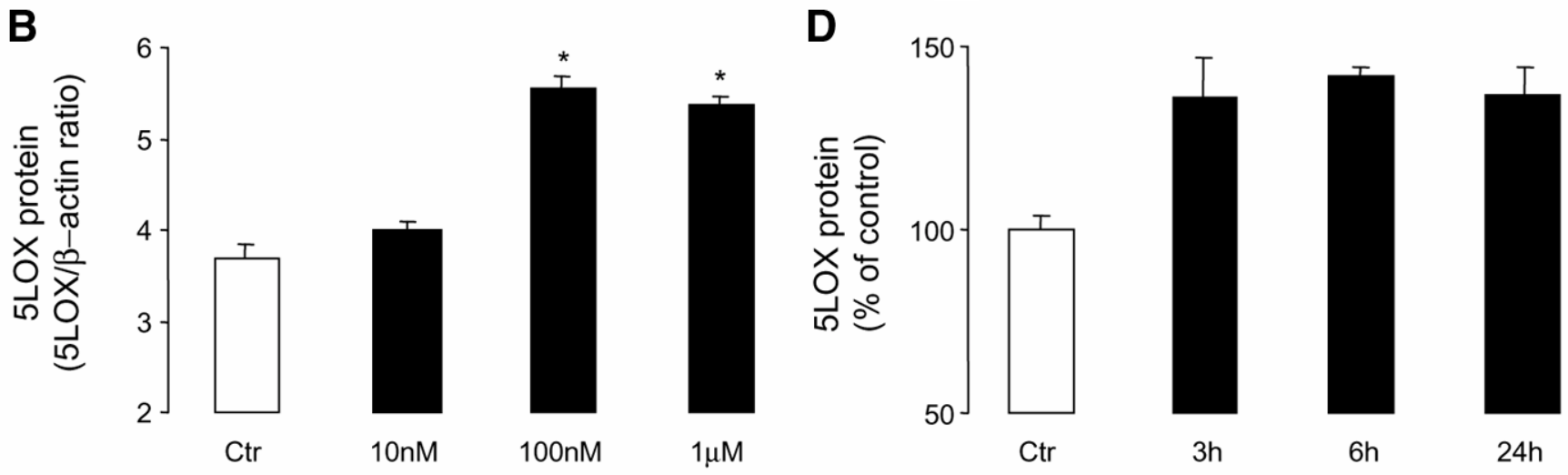

$24 \mathrm{~h}$

Figure 1. Effect of dexamethasone on 5LOX mRNA (A, C) and protein $(B, D)$ contents in primary cultures of CGN. Cultures were treated with increasing concentrations of dexamethasone for $24 \mathrm{~h} \mathrm{(A,} \mathrm{B),} \mathrm{or}$ with $1 \mu \mathrm{M}$ dexamethasone for indicated periods of time (3-24 h; C, D). Experiments were performed in 3-4 different culture preparations (A, B: the bars represent mean $\quad \mathrm{SE}$; $* P<0.01$ vs. vehicle-treated control; i.e., Ctrl), or in two different culture preparations ( $\mathbf{C}, \mathbf{D}$ : the bars are mean values expressed as percentage of corresponding time controls: each time point had its own vehicle- and dexamethasone-treated group). Note the increase with $100 \mathrm{nM}$ and $1 \mu \mathrm{M}$ dexamethasone $(\mathbf{A}, \mathbf{B})$. More than a 2.5 -fold increase in mRNA $(\mathbf{C})$, and about a 50\% increase in protein (D) contents were already observed after $3 \mathrm{~h}$ of dexamethasone treatment. 
Fig. 2

\section{A}

GR

$\beta$-actin

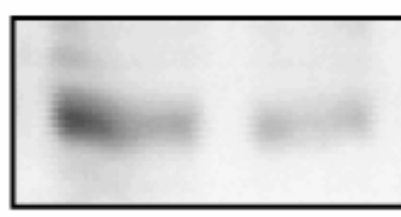

$\leftarrow 95 \mathrm{kD}$

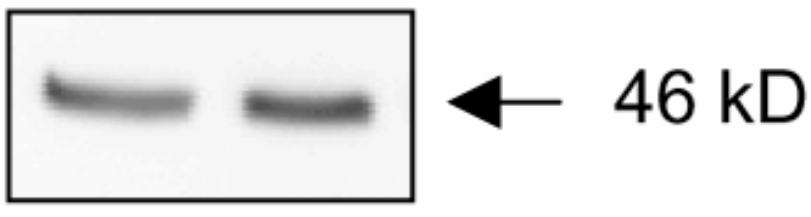

\section{SCRM AS}

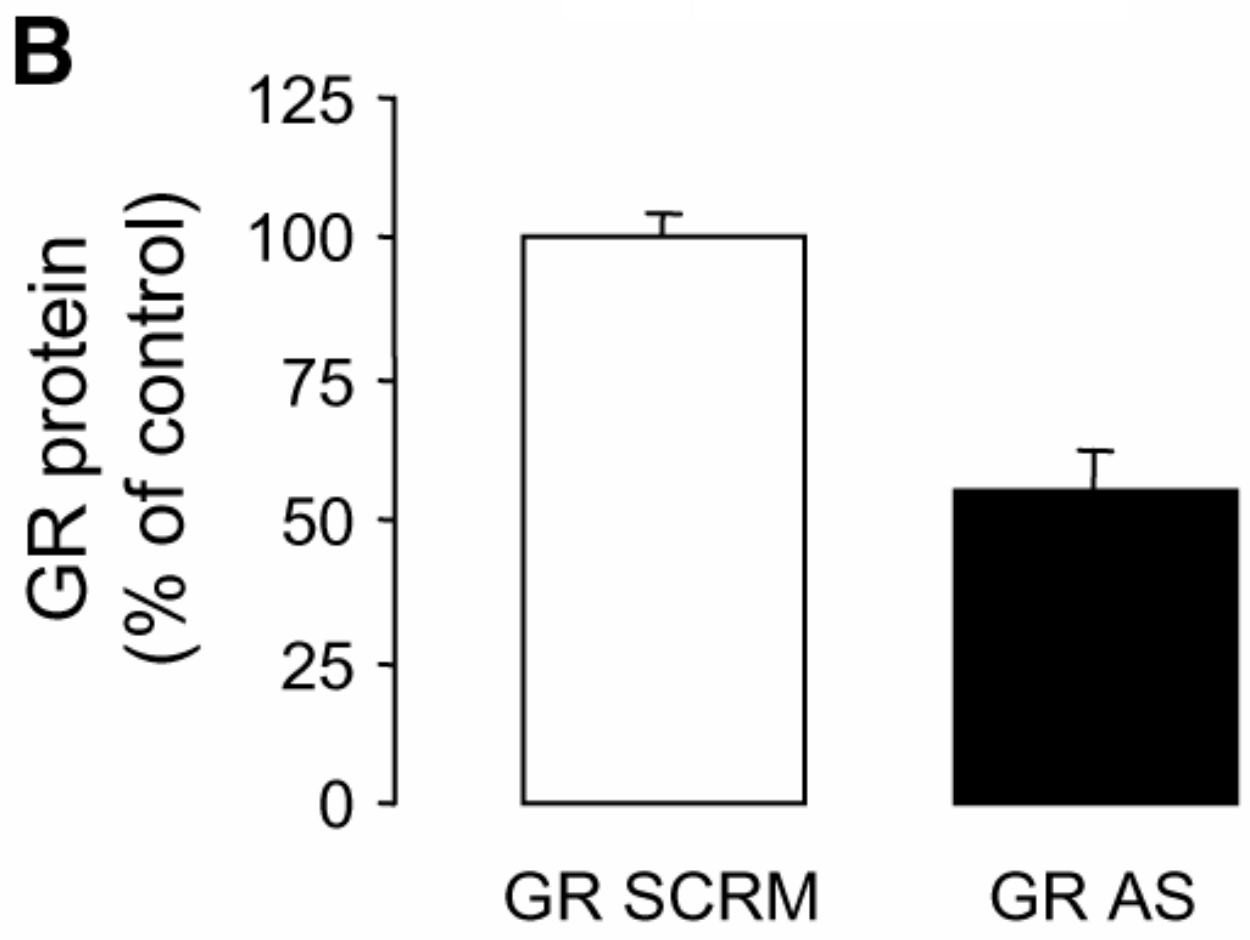

Figure 2. Glucocorticoid receptors in CGN cultures: suppression by antisense treatment. The GR antisense (AS) and the corresponding control, scramble (SCRM) oligonucleotides were dissolved in the culture medium and added to cells twice within $24 \mathrm{~h}$ at 12-h intervals; final concentration $10 \mu \mathrm{M}$ ); cells were processed $12 \mathrm{~h}$ after the second application of oligonucleotides. Treatment with AS reduced the content of GR-immunoreactive protein: A) shows an example blot (GR and $\beta$-actin immunostaining); B) Shows the results from two different preparations (mean values expressed as percentage of untreated control: GR/ $\beta$-actin ratios). 
Fig. 3

A

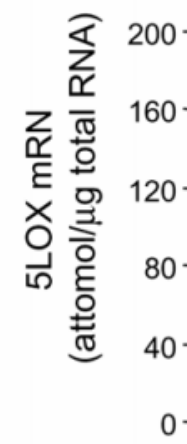

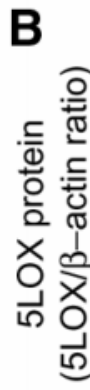

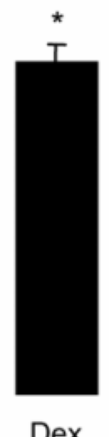

Dex

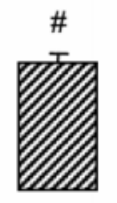

AS+Dex

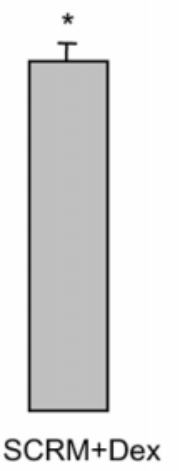

C
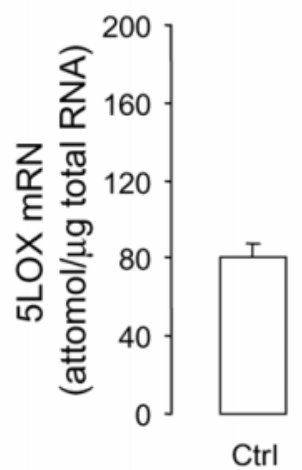

Ctrl

D

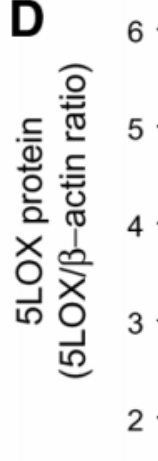

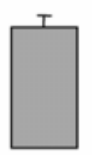

RU486
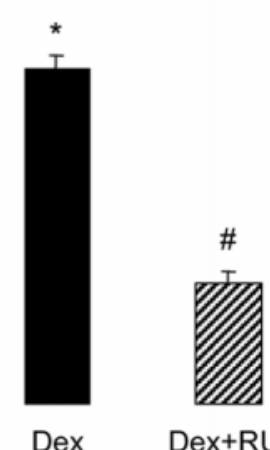

Dex+RU486

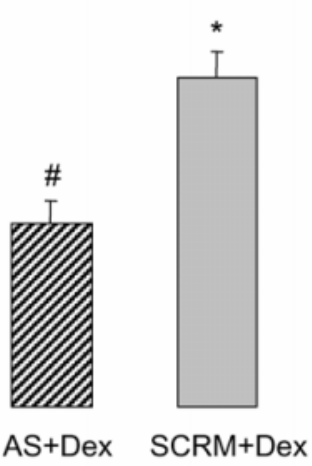

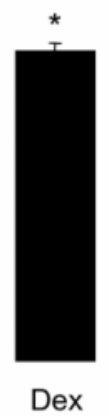

AS+Dex

Dex

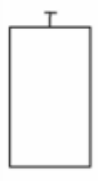

Ctrl
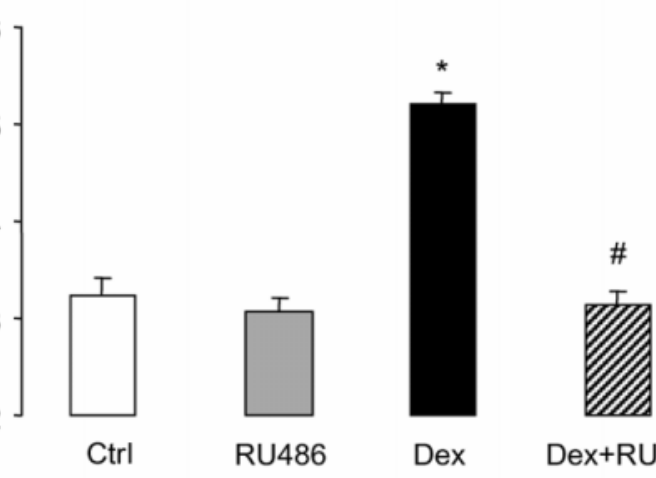

Dex+RU486

Figure 3. Treatment of CGN with GR antisense prevents the stimulatory action of dexamethasone on 5LOX mRNA (A) and protein (B) expression. Treatment with oligonucleotides, AS or SCRM was performed as described in Figure 2. Dexamethasone (Dex; $1 \mu \mathrm{M}$ ) or its vehicle (control; Ctrl) were included at the beginning of oligonucleotide treatment (i.e., for $24 \mathrm{~h}$ ). AS but not SCRM prevented the stimulatory action of dexamethasone on 5LOX mRNA (A) and protein (B) expression ( $n=3$ different preparations; mean \pm SE; $P<0.05: * v s$. Ctrl, \# vs. Dex). Pharmacological inhibition of GR prevents the stimulatory action of dexamethasone on 5LOX mRNA (C) and protein (D) expression. Cultures were treated for $24 \mathrm{~h}$ with $1 \mu \mathrm{M}$ dexamethasone (Dex) in the prelence or absence of $1 \mu \mathrm{M}$ RU486 (GR antagonist). The GR antagonist prevented dexamethasone from increasing 5 LOX mRNA $(\mathbf{C})$ and protein $(\mathbf{D})$ expression $(n=3$ different preparations; mean \pm SE; $P<0.05$ : *vs. Ctrl, \# vs. Dex). 
Fig. 4

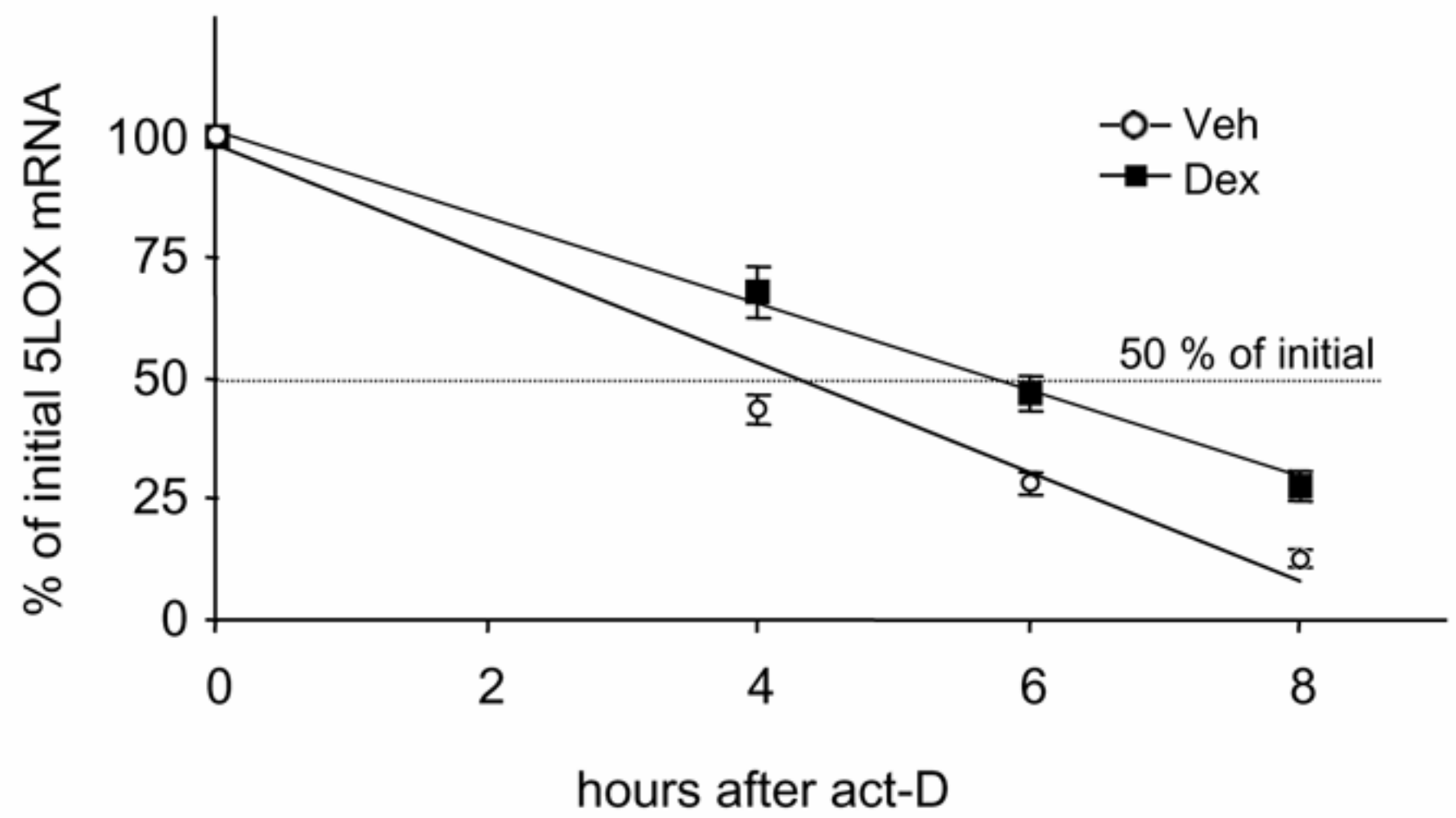

Figure 4. Dexamethasone treatment increases 5LOX mRNA half life in CGN cultures. The half-life of mRNA was assayed by measuring the 5LOX mRNA content following inhibition of gene transcription with actinomycin D (act-D; 10 $\mu \mathrm{g} / \mathrm{ml}$ ). Cultures were treated with dexamethasone or its vehicle for $24 \mathrm{~h}$ before the addition of actinomycin D; total RNA was isolated from vehicle- and dexamethasone-treated cells at different times after actinomycin D and 5LOX mRNA levels were measured by quantitative RT-PCR. This experiment was repeated three times; that is, in three different culture preparations. The time actinomycin D needed to reduce 5LOX mRNA content by $50 \%$ was increased by dexamethasone from $4.0 \pm 0.1$ to $5.8 \pm 0.20(P<0.01 ; n=3)$. 